The American Naturalist. Vol. iii., Nos. 8, 9, and 10. Salem, Mass. The American Entomologist. Vol. ii., Nos. I and 2.St. Louis, Mo.

The American Agriculturist. New York.

The Canadian Farmer. Toronto.

The Maine Farmer. Augusta, Me.

The (Weekly) N. Y. Sun. New York.



The Educator. London, Ont. Vol. ii., No. 12. An illistrated monthly.

\title{
TO CORRESPONDENTS.
}

W. V. A., New York.-Your subscription to Vol. ii. was duly received and put to your credit; by an oversight it was omitted from the list of acknowledgements. Your were right in sending $\$ 1.25 ; \$ 1.00$ is the price in gold, the basis of our Canadian currency.

Back Numbers.-In answer to numerous enquiries we beg to state that we can supply a limited number of copies of our first volume, neatly bound in the wrapper, for one dollar each. We have also plenty of copies of all the numbers frcm the beginning except Nos. 1, 3 and 4 of Vol. i.; we shall gladly pay ten cents apiece for copies of any of these three numbers sent to us in good order.

S. H., Boston.-We have a few feet left of the extra thick cork, at 24 cents per square foot, but none of the ordinary thickness. We shall get a fresh supply of the latter from England shortly.

PIns.-We have still on hand a quantity of Klacger's entomological pins, Nos. 4, 5 and 6 , price 50 cents (gold) per package of 500 . These are the coarser sizes; we have ordered a fresh supply of Nos. 1, 2 and 3.

Subscriptions.-Members of the Society are reminded that their subscriptions for the year 1870 (\$2) are now due.

Donation.-Mr. J. Pettit, of Grimsby, in making a remittance, kindly presented the balance, $\$ 2.25$, to the publication fund.

* * In future we shall acknowledge subscriptions to the Canadian Eritomologist by enclosing a receipt for the amount received in the subscriber's copy, as the law permits, instead of in our pages as heretofore.

We crave the indulgence of many of our correspondents for having permitted their letters to remain so long unanswered. Entomology is with us a labour of love; other, and more pressing and important duties frequently prevent our devoting to it as much time as we would.

CLub Rates.--In addition to the club rates announced on the second page of the wrapper, we are enabled to offer the following:-

The American Agriculturist $(\$ 1.50)$ and the Canadian Entomologist (\$1) for $\$ 2.00$.

Once a Month (\$2) and the Canadian Entomologist (1) for $\$ 2.25$.

- Arthur's Home Magazine (\$2) and the Canadian Ent. (\$1) for $\$ 2.25$.

The Children's Hour (\$1.25) and the Canadian Ent. (\$1) for $\$ 1.75$.

The Educator (36 cents) and the Canadian Entomologist (\$1) for \$1.05. 


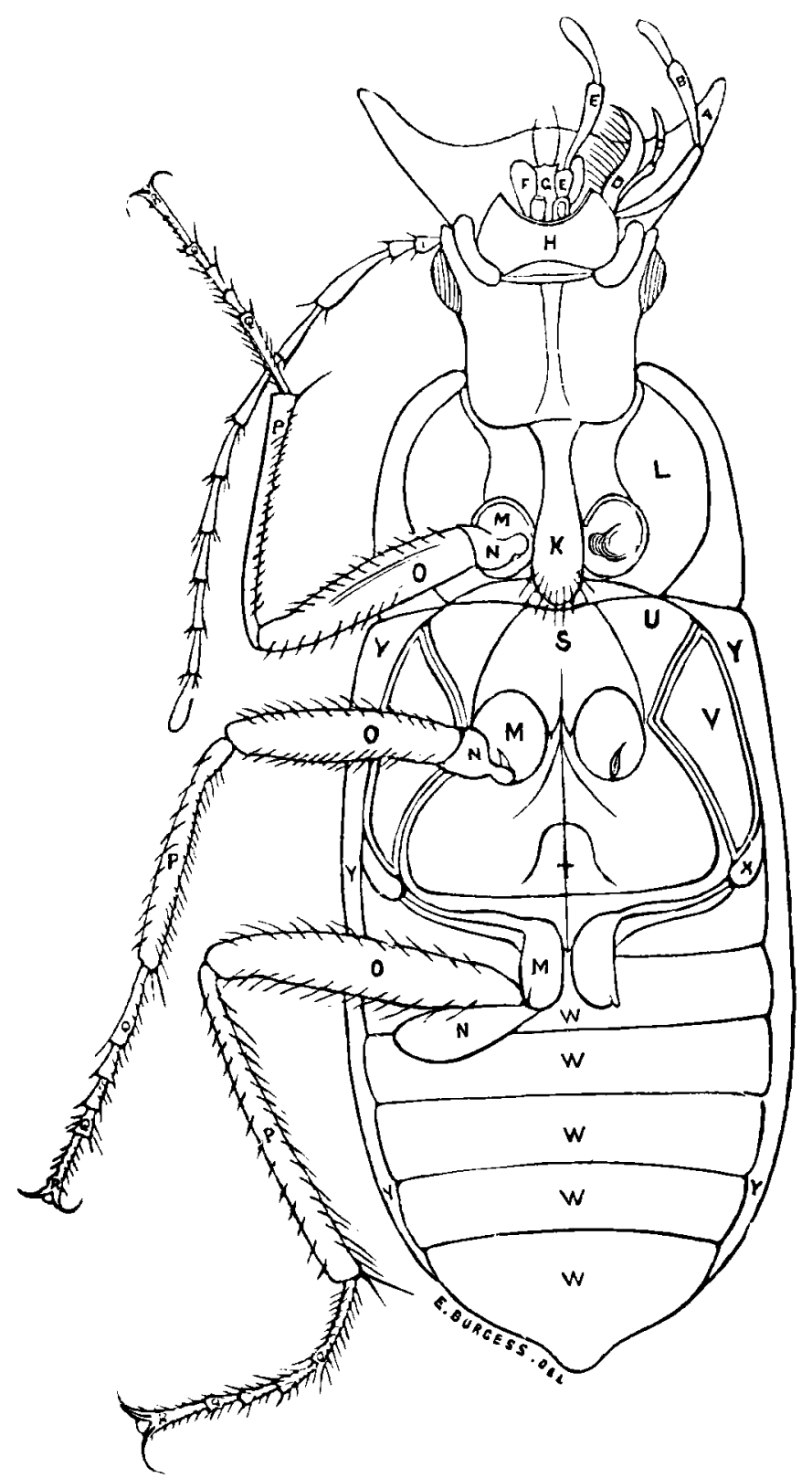

Harpalus Caljginosus, Say. $q$. 


\section{PARTS OF CUT.}

Ventral surface of Harpalus caliginosus.
A Mandible.
K Prosternum.
S Mesosternum.
B Maxillary palpus.
L Episternum or protho- $\mathrm{T}$ Metasternum.
C Outer lobe of maxilla.
rax.
$\mathrm{U}$ Episternum of meso
D Inner lobe of maxilla. M. Coxae.
E Labial palpus. N Trochanter. torax.
F Paraglossæ.
O Femora.
$\mathrm{V}$ Episternum of meta torax.
G Ligula.
P Tibia.
H Mentum.
Q Tarsi.
I Antenna.
R Ungues.
W Ventral segments.
$X$ Epimeron of metatho-
Y Epipleura. [rax.

EXPLANATION OF TERMS.

Base-That point of any organ nearest the centre of the insect.

Apex-That point of any organ farthest from the centre of the insect.

Dorsal-Upper surface.

Ventral-Under surface.

Emarginate-Sharp indentation.

sinuate-Curved indentation.

Lateral-Pertaining to the sides.

Marginate-With the edge surrounded by a border.

Truncate-Squarley cut.

Transwise-Crosswise

Obtuse-Rounded, not acute.

Ccute-Pointed.

Thorax-Usually the dorsal surface between the head and the elytra. attached.

Prothorax-Usually the ventral surface to which the anterior legs are

Mesothorax-That part to which the middle legs are attached.

Metathorax-That part to which the posterior legs are attached.

Elytra-The wing covers.

Elytral strice-Longitudinal grooves in wing covers.

Elytral interstices-Spaces between the stria.

Elytral dorsal punctures-Small impressions usually between the first and third strix.

Scutel-Triangular piece at the base of the suture of wing covers.

Scutellar stria-Abbreviated strix each side of the scutel.

Suture-The longitudinal line of juncture between the wing covers.

Sutural stria-The groove next to the suture.

Rugose-Wrinkled.

Sulcate-Broad shallow groove.

Fovea-Large impression.

Connate-Joined together.

Reticulate-Covered with lines intersecting each other like a net. 